\title{
PERANCANGAN DAN IMPLEMENTASI ALAT PENGUKUR KADAR NATRIUM DALAM CAIRAN
}

\section{DESIGN AND IMPLEMENTATION MEASURING DEVICE OF SODIUM LEVEL IN LIQUID}

\author{
Miftahul Fawaz1)*, Raditiana Patmasari2), R Yunendah Nur Fu'adah3), \\ \& Azis Ansori Wahid4) \\ 1)Prodi $S 1$ Teknik Telekomunikasi, Fakultas Teknik Elektro, Universitas Telkom, Indonesia \\ 2)Prodi S1 Teknik Telekomunikasi, Fakultas Teknik Elektro, Universitas Telkom, Indonesia \\ 3)Prodi S1 Teknik Telekomunikasi, Fakultas Teknik Elektro, Universitas Telkom, Indonesia \\ 4)Fakultas Farmasi dan Laboratorium Medik, Institut Kesehatan Rajawali, Indonesia
}

Diterima: Agustus 2020; Disetujui: November 2020; Dipublikasi: Februari 2021

*Coresponding Email: miftahulfawaz@gmail.com

\section{Abstrak}

Elektrolit adalah senyawa yang sangat penting untuk mendukung proses metabolisme dalam tubuh. Alat untuk melakukan pengukuran kadar elektrolit dalam darah biasa disebut Electrolyte Analyzer. Alat yang tersedia saat ini memiliki harga yang relatif mahal dikarenakan harus di import dari luar negeri. Oleh karena itu, penulis mencoba membuat perangkat pendeteksi elektrolit yang sederhana. Komponen terpenting dari alat ini adalah Ion Selective Electrode untuk mengukur tegangan dalam cairan elektrolit. Selain itu, terdapat komponen pendukung seperti multimeter. Setelah mendapatkan data, data akan dibagi menjadi 2 yaitu data uji dan data latih untuk mengelompokan kadar elektrolit. Pengelompokan menggunakan metode klasifikasi k-Nearest Neighbour (k-NN) ke dalam kondisi normal, hiponatremia, dan hipernatremia. Hasil akhir dari penelitian ini adalah sebuah alat yang digunakan untuk melakukan pengukuran kadar elektrolit dalam cairan dan dikelompokan dengan Matlab. Data diambil dari cairan sampel dengan konsentrasi 110, 115, 120, 125, 130, 135, 140, 145, 150, dan 154 mmol/L. Pengujian yang dilakukan adalah penentuan nilai kadar elektrolit dan pengujian waktu kalibrasi yang memperoleh tingkat akurasi 99,7\% dengan skema melalukan kalibrasi setiap satu kali pembacaan cairan sampel. Sedangkan untuk pengelompokan, nilai akurasi tertinggi adalah 75\% dengan menggunakan metode kNN dengan pengukuran jarak Euclidean, City-Block, Chebychev, dan Minkowski dengan nilai k=1 dan k=3.

Kata kunci: Elektrolit, Ion Selective Electrode, k-NN

\section{Abstract}

Electrolytes are compounds that are important to support metabolic processes in human body. A device for measuring electrolyte levels called an Electrolyte Analyzer. The device available today are relatively expensive because they have to be imported from abroad. Therefore, the authors tried to make a simple electrolyte detection device. The most important component of this device is the Ion Selective Electrode to measure the voltage electrolyte. In addition, there are supporting components such as a multimeter. After getting the data, data will be divided into test data and training data to classify electrolyte levels. Grouping using the $k$-Nearest Neighbor classification method into normal conditions, hypoatremia, and hyperatremia. The result is a device used to measure electrolyte levels in liquids and is group. Data were taken from fluid samples with concentrations of 110,115, 120,125, 130,135, 140, 145, 150, and 154 
mmol/L. The tests carried out were determining the value of electrolyte levels and testing the time of calibration which obtained an accuracy rate of $99.7 \%$ with the scheme of calibration before performing the measurement of sample fluid. As for grouping, the highest accuracy value is $75 \%$ using the $k$-NN method with all distance measurements with $k=1$ and $k=3$.

Keywords: Electrolytes, Ion Selective Electrode, $k$-NN

How to Cite: Fawaz. M, Patmasari. R, Fu'adah, R. Y. N, Wahid, A. A (2021). Perancangan Dan Implementasi Alat Pengukur Kadar Natrium Dalam Cairan. JESCE (Journal of Electrical and System Control Engineering). 4 (2): 72 - 


\section{PENDAHULUAN}

Elektrolit sangat penting dalam tubuh karena berfungsi untuk mendukung proses metabolisme dalam tubuh. Konsentrasi elektrolit yang tidak seimbang dapat menyebabkan beberapa gangguan dalam tubuh, seperti dehidrasi, diare, kram hingga kejang-kejang.

Saat ini tersedia alat pengukur elektrolit sudah dapat ditemukan di rumah sakit, biasa disebut electrolyte analyzer. Alat ini masih di import dari luar negeri sehingga memiliki harga yang relatif lebih mahal. Oleh karena itu, diperlukan alat alternatif yang dapat digunakan untuk pengukuran kadar elektrolit dalam cairan sampel. Komponen terpenting pada alat ini adalah membran selektif yang di atasnya terdapat cairan tertentu dan terdapat elektroda di dalamnya. Prinsip kerja alat ini adalah elektrolit yang terkandung dalam cairan menyentuh membran selektif tertentu dan membran referensi, setelah itu diukur tegangan elektrolit tersebut dan diubah dalam bentukmmol/L.

Elektrolit merupakan unsur atau senyawa yang jika melebur atau larut dalam pelarut akan menjadi ion dan dapat membawa muatan listrik.
Elektrolitsangat berpengaruh terhadap proses metabolisme. Elektrolit yang mayoritas terdapat dalam tubuh adalah natrium $(\mathrm{Na}+)$, kalium $(\mathrm{K}+)$, klorida (Cl-), dan bikarbonat (HICO3-). Kebutuhan elektrolit dalam tubuh berbeda-beda berdasarkan umur. Pada orang dewasa normalnya membutuhkan kandungan natrium sebesar 135-145 mmol/L. Konsentrasi elektrolit pun dapat dipengaruhi oleh aktivitas, usia, iklim, asupan makanan, stress dan penyakit. Jika konsentrasi elektrolit tidak normal maka dapat menyebabkan beberapa gangguan. Gangguan pada elektrolit natrium salah satunya adalah Hiponatremia dimana gangguan ini akan timbul jika dibawah kadar normal yaitu 130 mmol/L. Gejala yang akan timbul adalah bengkak karena retensi air, kembung, kejang, sakit kepala yang parah dan kejang. Hiponatremia dapat timbul disebabkan karena diare, muntah atau keringat yang sangat banyak. Selain hiponatremia, gangguan yang disebabkan elektrolit adalah hipernatremia. Gangguan ini disebabkan karena tingginya konsentrasi natrium dari batas normal. Jika konsentrasi natrium lebih dari 150 mmol/L maka akan timbul gejala 
perubahan mental, letargi, kejang, lemah dan koma.

Untuk mengukur elektrolit digunakan Ion Selective Electrode (ISE), alat ini tidak berfungsi untuk mengukur konsentrasi ion melainkan aktivitas ion tersebut. Aktivitas yang dimaksud adalah kriteria kemampuan ion untuk berinteraksi dengan ion lain. Konsentrasi ion dihitung berdasarkan aktivitas ion tersebut dan dipengaruhi oleh jumlah ion yang terdapat pada larutan tersebut.

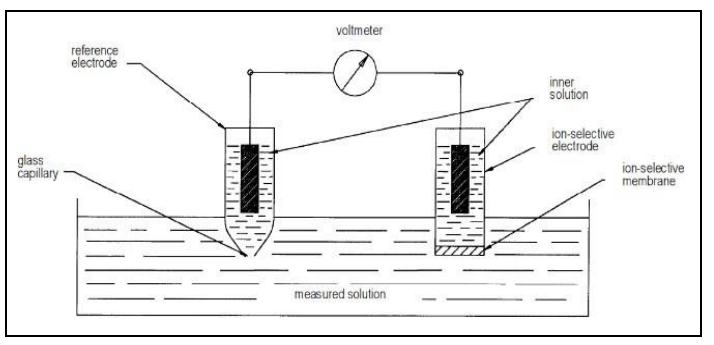

Gambar 1. Prinsip kerja Ion Selective Electrode

Prinsip kerja dari ion selective electrode adalah elektroda selektif ion harus tersambung ke elektroda reference untuk dapat mengukur aktivitas ion, ditampilkan pada Gambar 1. Saat kedua elektroda tersebut menyentuh sampel (darah atau urin) berlaku Persamaan Nernst. Dari persamaan Nernst akan didapatkan beda potensial dari ion yang diukur. Jika satu larutan yang sedang diukur diketahui konsentrasi ionnya, maka konsentrasi ion sampel dapat ditentukan atas dasar perbedaan dua pontensialyang diukur dengan:

$$
C_{\text {isampel }}=c_{i \text { standard }} \times 10^{\left(\frac{A E}{s}\right)}
$$

Dimana $\Delta \mathrm{E}$ adalah perbedaan antara potensial yang diukur dari sampel dan standar, $\mathrm{S}$ adalah beda potensial dari elektroda yang ditentukan dari beda potensial dari dua larutan standar yang diukur, $C_{\text {isampel }}$ adalah konsentrasi ion yang diukur pada sampel, dan $C_{i \text { standard }}$ adalah konsentrasi ion yang diukur dalam larutan standar. Persamaan 1 menyatakan konsentrasi ionyang tidak diketahui dalam sampel.

Sebagai contoh, akan melakukan pengukuran sampel dengan konsentrasi tidak diketahui. Pertama dilakukan pengukuran terhadap larutan standard dengan konsentrasi $110 \mathrm{mmol} / \mathrm{L}$ dan $140 \mathrm{mmol} / \mathrm{L}$. Selanjutnya dari pengukuran yang didapat nilai tegangan untuk larutan standard $110 \mathrm{mmol} / \mathrm{L}$ adalah 72,6 mV, sedangkan untuk $140 \mathrm{mmol} / \mathrm{L}$ adalah $82,11 \mathrm{mV}$. Setelah didapatkan nilai konsentrasi standard, dilakukan pengukuran terhadap tegangan sampel. Tegangan sampel yang didapat adalah 74, $02 \mathrm{mV}$. Dikarenakan nilai tegangan sampel lebih kecil dibandingkan tegangan standard $140 \mathrm{mmol} / \mathrm{L}$, maka yang digunakan 
sebagai acuan adalah cairan standard $110 \mathrm{mmol} / \mathrm{L}$. Selanjutnya dihitung menggunakan Persamaan 1, sehingga

$$
C_{\text {isampel }}=110 \times 10^{\left(\frac{74.03-72.65}{74,03}\right)}
$$

Didapatkan nilai konsentrasi sampel adalah 115, $06 \mathrm{mmol} / \mathrm{L}$.

Cairan standar merupakan larutan elektrolit yang memiliki macammacam elektrolit di dalamnya. Cairan ini dibuat oleh pabrik dan di dalam cairan ini terdapat berbagai macam elektrolit yang sudah besarnya dan dibuat sedemikian diketahui rupa agar tidak dapat mudah berubah kandungan elektrolit yang ada. Dalam satu kemasan terdapat 2 jenis cairan standar yang memiliki kadar elektrolit yang berbeda. Setelah diperoleh nilai kadar natrium dari ISE, dilakukan pengklasifikasian menggunakan $k$ nearest neighbor. Klasifikasi $k$-nearest neighbor adalah salah satu klasifikasi yang sederhana. Klasifikasi $k$-nearest neighbour merupakan algoritma semisupervised karena membutuhkan data latih dan juga uji. Jarak merupakan pendekatan yang digunakan untuk menentukan kesamaan dua vektor fitur. Algoritma k-NN memiliki langkah pengklasifikasian, pertama dengan mengumpulkan data latih yang merupakan kumpulan dari beberapa variabel. Setelah itu, data input akan dibandingkan dengan data referensi yang ada. Selanjutkan akan melakukan pertimbangan pada titik yang terdekat menggunakan beberapa pengukuran jarak. Semakin kecil jarak yang di dapat, maka semakin besar kesamaannya. Pengukuran jarak dapat dilakukan dengan metode Euclidean, City-Block, Chebyshev, dan Minkowski. Pengukuran jarak digunakan pada aplikasi Matlab dan menggunakan fitur yang ada dengan coding yang dibuat agar dapat melakukan perhitungan jarak dengan cepat.

\section{METODE PENELITIAN}

Pada penelitian ini, sistem yang digunakan adalah menguji dari cairan sampel yang sudah diketahui kadar elektrolitnya menggunakan multimeter dan dikelompokkan dengan klasifikasi k- nearest neighbor. 


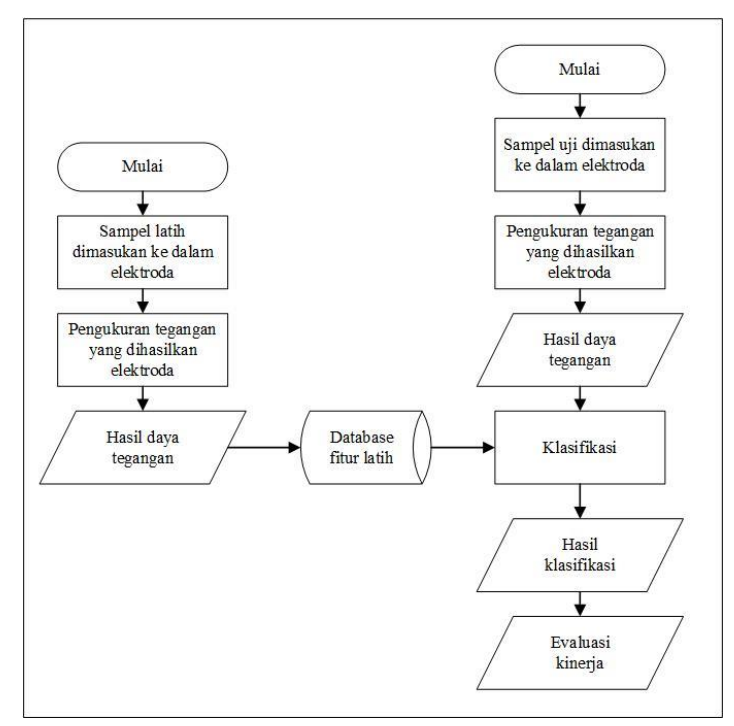

Gambar 2. Perancangan sistem

Gambar 2 menunjukkan perancangan sistem dari penelitian ini. Langkah pertama yang dilakukan pada penelitian ini adalah sampel-sampel dari cairan akan melewati ion selective electrode. Ion selective electrode terhubung dengan multimeter untuk mengukur potensial listrik yang dihasilkan dari sampel tersebut dan dikonversikan menggunakan Persamaan 1. Selanjutnya, data akan diolah dengan aplikasi Matlab untuk melakukan pengklasifikasian menggunakan k-nearest neighbor yang akan menghasilkan kondisi normal, hiponatremia, dan hipernatremia. Pada aplikasi matlab terdapat fitur perhitungan k-NN dengan menggunakan coding yang ada. Kita hanya mengganti variabel $\mathrm{k}$ dengan yang kita inginkan dan jenis k-NN yang akan digunakan.

Elektroda selektifakan menghasilkan tegangan yang diakibatkan karena larutan pada elektroda bereaksi dengan ion-ion yang ada dalam sampel. Cairan akan didiamkan di dalam elektroda selama 35 detik agar mendapat nilai yang stabil. Setelah mendapatkan nilai tegangan, data akan dibagi menjadi 2, yaitu data uji dan data latih. Hasil dari perancangan sistem adalah sebuah database fitur kondisi normal, hiponatremia, dan hipernatremia.

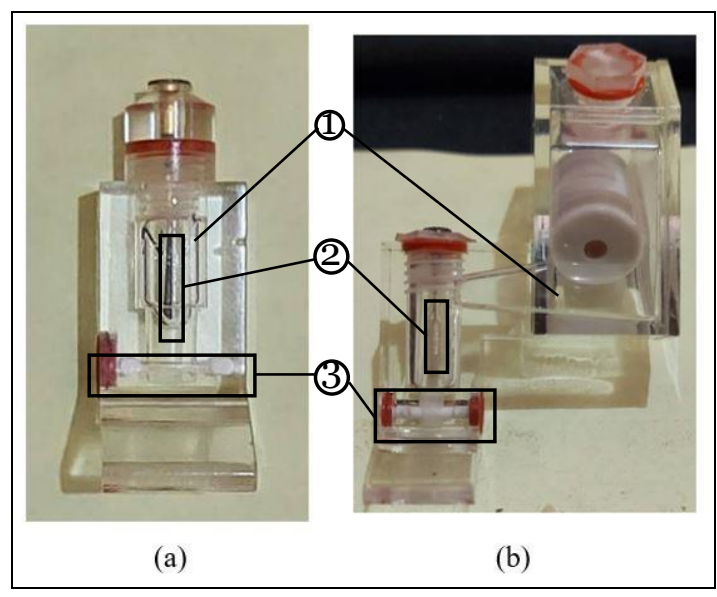

Gambar 3. (a) Elektroda Natrium dan (b) Elektroda Reference

Elektroda natrium (Gambar 3 (a)) merupakan komponen yang sangat penting dikarenakan di dalam elektroda tersebut terdapat membran yang dapat memisahkan kandungan natrium dari cairan sampel. Elektroda reference (Gambar 3 (b)) merupakan 
elektroda (Gambar 3 (1)) yang berfungsi sebagai ground dari rangkaian elektroda agar menghasilkan tegangan. Kedua elektroda harus terhubung dengan cairan yang sama dengan cara memasukan cairan sampel kedalam pipa kapiler (Gambar 3 (3)) agar dapat menghasilkan tegangan yang ditimbulkan karena adanya aktifitas ion. Setelah melewati membran yang terdapat pada kedua elektroda selektif, selanjutnya sampel yang sudah dipisahkan dihubungkan antara membran dan elektroda menggunakan inner solution (Gambar 3 (2).

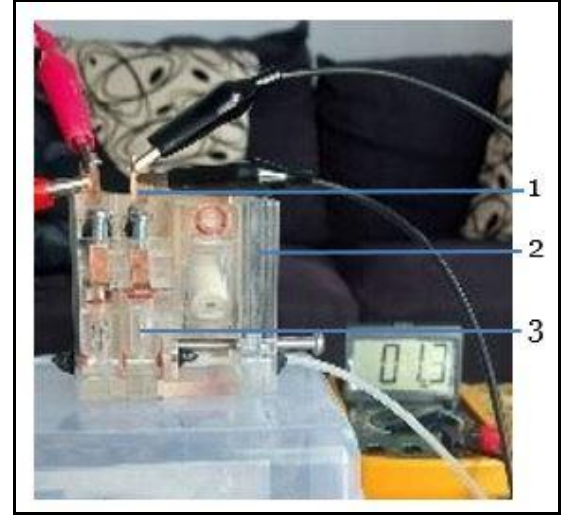

Gambar 4. Hasil Rancangan Alat

Pada penelitian ini, agar alat dapat digunakan dilakukan pembuatan dudukan dari kedua elektroda yang terbuat dari bahan akrilik (Gambar 4 (2)). Setelah sudah terbentuk dudukannya, dilakukan penyambungan

antara elektroda selektif dan multimeter menggunakan tembaga (Gambar 4 (1)). Selanjutnya dilakukan perencanaan perangkat lunak dilakukan menggunakan perangkat Matlab R2018a dengan menggunakan metode klasifikasi k-NN. Blok bagian kiri pada Gambar 2 merupakan tahap pelatihan sistem dan bagian kanan merupakan tahap pengujian sistem. Setelah memulai sistem, dilakukan pengukuran tegangan yang dihasilkan oleh elektroda. Pengukuran tegangan dilakukan dengan cairan sampel masuk kedalam elektroda dan mengenai kedua elektroda (Na dan Referensi). Setelah itu, tegangan yang dihasilkan akan dibaca menggunakan multimeter dengan waktu pengukuran 35 detik.

Setelah diperoleh nilai tegangan cairan sampel, diambil data yang memiliki akurasi 75\% dan dilakukan pembagian data menjadi 2, yaitu data latih sebanyak 30 data dan data uji sebanyak 20 data. Data tersebut akan dimasukan ke dalam database fitur, dimana database tersebut akan digunakan pada tahap klasifikasi. Hasilnya kadar elektrolit akan dikategorikan menjadi normal, hiponatremia, dan hipernatremia.

Pengklasifikasian dilakukan dengan 
menggunakan k-NN dan menggunakan 2 fitur serta dibandingkan dengan 1 fitur, dimana 2 fitur adalah konsentrasi yang diperoleh dari 2 referensi (110 \& $140 \mathrm{mmol} / \mathrm{L})$, dan 1 fitur adalah konsentrasi terpilih dari cairan sampel. Selain itu, dilakukan juga pengujian menggunakan metode perhitungan jarak Euclidean, CityBlock, Chebychev, danMinkowski.

\section{HASIL DAN PEMBAHASAN}

Pengujian nilai kadar elektrolit merupakan pengujian untuk menilai hasil yang dikeluarkan dari ion selective electrode (ISE). Pengujian ini dilakukan dengan cara menguji beberapa macam sampel cairan $\mathrm{NaCl}$ yang sudah diketahui nilai kadarnya. Setelah itu, hasil tegangan yang dihasilkan oleh ISE dikonversikan menjadi besar nilai kadar elektrolit sampel menggunakan Persamaan 1. Sampel yang digunakan terdiri dari kadar 110, 115, 120, 125, 130, 135, 140, 145, 150, dan $154 \mathrm{mmol} / \mathrm{L}$.

Untuk memperoleh hasil nilai kadar elektrolit, diperlukan pengukuran tegangan cairan standar dimana cairan ini akan dijadikan referensi dalam perhitungan untuk mendapatkan nilai kadar elektrolit yang dicari.
Pengukuran tegangan cairan standar dilakukan dengan melakukan 10 kali percobaan dengan nilai konsentrasi $110 \mathrm{mmol} / \mathrm{L}$ dan $140 \mathrm{mmol} / \mathrm{L}$. Pada setiap percobaan tegangan diukur setiap 5 detik dari mulai detik ke 15 hingga detik ke 35, kemudian hasil dari tegangan tersebut dirata-ratakan untuk mendapat nilai rata-rata setiap konsentrasi pada setiap percobaan. Dari hasil rata rata pada setiap percobaan kemudian dihitung nilai rata-rata dari setiap konsentrasi untuk keseluruhan. Tabel 1 merupakan hasil nilai rata-rata pada keseluruhan percobaan.

Tabel 1. Hasil rata-rata tegangan cairan standar

\begin{tabular}{ccc} 
& \multicolumn{2}{c}{ Hasil $(\mathrm{mV})$} \\
Ke- & $\begin{array}{c}110 \\
\text { mmol/L }\end{array}$ & $140 \mathrm{mmol} / \mathrm{L}$ \\
\cline { 2 - 3 } 1 & 78,68 & 86,18 \\
\hline 2 & 92,04 & 107,72 \\
\hline 3 & 90,1 & 104,52 \\
\hline 4 & 92,5 & 104,8 \\
\hline 5 & 95,84 & 103,32 \\
\hline 6 & 97,98 & 106 \\
\hline 7 & 99,48 & 104,92 \\
\hline 8 & 102,52 & 103,54 \\
\hline 9 & 104,36 & 106,06 \\
\hline 10 & 97,82 & 105,96
\end{tabular}




\section{Rata-Rata $\quad 95,132 \quad 103,302$}

Setelah mendapatkan nilai standar untuk $110 \mathrm{mmol} / \mathrm{L}$, yaitu 95,135 mV dan untuk $140 \mathrm{mmol} / \mathrm{L}$, yaitu 103,302 $\mathrm{mV}$, dilakukan pengukuran tegangan cairan sampel yang telah disebutkan dengan cara yang sama, yaitu mengukur tegangan yang terbaca dengan jarak waktu 5 detik dimulai dari 15 hingga 35 detik. Kemudian dihitung nilai rata-rata setiap percobaan pada setiap sampel. Setiap sampel dilakukan percobaan sebanyak 10 kali, kemudian diukur nilai tegangan cairan sampel per konsentrasi untuk keseluruhan percobaan. Setelah mendapatkan nilai rata-rata cairan sampel, dilakukan konversi menggunakan Persamaan 1 untuk mendapatkan nilai kadar elektrolit. Jika nilai rata-rata tegangan sampel dibawah nilai tegangan cairan standar $140 \mathrm{mmol} / \mathrm{L}$ maka nilai referensi yang dipakai adalah nilai tegangan cairan standar $110 \mathrm{mmol} / \mathrm{L}$. Jika nilai tegangan cairan sampel diatas nilai tegangan cairan standar $140 \mathrm{mmol} / \mathrm{L}$ maka tetap digunakan nilai referensi tegangan cairan standar $140 \mathrm{mmol} / \mathrm{L}$. Tabel 2 merupakan hasil nilai tegangan rata-rata pada cairan sampel dan hasil konversi ke nilai kadar elektrolit.
Tabel 2. Hasil nilai tegangan rata-rata pada cairan sampel dan hasil konversi

\begin{tabular}{|c|c|c|c|c|}
\hline \multicolumn{2}{|c|}{ Cairan (mmol/L) } & 110 & 115 & 120 \\
\hline \multicolumn{2}{|c|}{ Cairan Sampel } & 95,17 & 97,97 & 97,60 \\
\hline \multirow{2}{*}{$\Delta \mathrm{E}(\mathrm{mV})$} & $\begin{array}{c}110 \\
\mathrm{mmol} / \mathrm{L}\end{array}$ & 0,03 & 2,84 & 2,47 \\
\hline & $\begin{array}{c}140 \\
\mathrm{mmol} / \mathrm{L}\end{array}$ & $-8,14$ & $-5,33$ & $-5,70$ \\
\hline \multirow{3}{*}{$\begin{array}{c}\text { Hasil } \\
\text { Konversi } \\
\text { (mmol/L) }\end{array}$} & 110 & 110,0 & 117,8 & 116,7 \\
\hline & $\mathrm{mmol} / \mathrm{L}$ & 9 & 3 & 8 \\
\hline & $\begin{array}{c}140 \\
\mathrm{mmol} / \mathrm{L}\end{array}$ & $\begin{array}{c}167,8 \\
4\end{array}$ & $\begin{array}{c}157,6 \\
6\end{array}$ & \\
\hline
\end{tabular}

\begin{tabular}{|c|c|c|c|}
\hline Cairan (mmol/L) & 125 & 130 & 135 \\
\hline Rata-Rata Tegangan & & 100,4 & \\
\hline Cairan Sampel & & 7 & \\
\hline
\end{tabular}

\begin{tabular}{ccccc}
\hline \multirow{2}{*}{$\Delta \mathrm{E}(\mathrm{mV})$} & $\begin{array}{c}110 \\
\mathrm{mmol} / \mathrm{L}\end{array}$ & 4,29 & 5,33 & 6,95 \\
\cline { 2 - 5 } & 140 & & \\
& $\mathrm{mmol} / \mathrm{L}$ & & & \\
\hline Hasil & 110 & 122,0 & 125,1 & 130,1 \\
Konversi & $\mathrm{mmol} / \mathrm{L}$ & 4 & 6 & 5 \\
\cline { 2 - 5 } (mmol/L) & 140 & 152,6 & 149,1 & 140,1 \\
& $\mathrm{mmol} / \mathrm{L}$ & 4 & 4 & 9 \\
\hline
\end{tabular}

\begin{tabular}{rcccc}
\hline $\begin{array}{c}\text { Cairan } \\
\text { (mmol/L) }\end{array}$ & 140 & 145 & 150 & 154 \\
\hline Rata-Rata & 102,0 & 103,3 & 105, & 105, \\
Tegangan & 8 & 6 & 16 & 7 \\
Cairan Sampel & & & & \\
\hline 110 & 8,23 & 8,89 & 10,0 & 10,7
\end{tabular}




\begin{tabular}{|c|c|c|c|c|c|}
\hline \multirow[t]{2}{*}{$\begin{array}{c}\Delta \mathrm{E} \\
(\mathrm{mV})\end{array}$} & $\begin{array}{c}\mathrm{mmol} / \\
\mathrm{L}\end{array}$ & & & 2 & 7 \\
\hline & $\begin{array}{c}140 \\
\mathrm{mmol} / \\
\mathrm{L}\end{array}$ & 0,06 & 0,72 & 1,85 & 2,60 \\
\hline $\begin{array}{l}\text { Hasil } \\
\text { Konver }\end{array}$ & $\begin{array}{c}110 \\
\mathrm{mmol} / \\
\mathrm{L}\end{array}$ & $\begin{array}{c}134,2 \\
5\end{array}$ & $\begin{array}{c}136,4 \\
1\end{array}$ & $\begin{array}{c}140 \\
21\end{array}$ & $\begin{array}{c}142 \\
7\end{array}$ \\
\hline $\begin{array}{c}\text { (mmol/ } \\
\text { L) }\end{array}$ & $\begin{array}{c}140 \\
\mathrm{mmol} / \\
\mathrm{L}\end{array}$ & $\begin{array}{c}140,1 \\
9\end{array}$ & $\begin{array}{c}142,2 \\
7\end{array}$ & $\begin{array}{c}145 \\
91\end{array}$ & $\begin{array}{c}148 \\
3\end{array}$ \\
\hline
\end{tabular}

Sebagai contoh, pada Tabel 2 nilai rata-rata tegangan cairan sampel 110 mmol/L adalah $95.166 \mathrm{mV}$. Nilai tersebut lebih kecil dibandingkan dengan nilai rata- rata cairan standar $140 \mathrm{mmol} / \mathrm{L}$ yaitu 103.302, maka hasil konversi yang digunakan adalah 110,0906 mmol/L dimana nilai kadar elektrolit tersebut menggunakan tegangan standar $110 \mathrm{mmol} / \mathrm{L}$ sebagai referensi. Untuk nilai rata- rata tegangan sampel $150 \mathrm{mmol} / \mathrm{L}$ diperoleh nilai yang lebih besar dibandingkan dengan nilai rata-rata tegangan cairan standar $140 \mathrm{mmol} / \mathrm{L}$, maka nilai konversi yang digunakan adalah 145,9068 mmol/L.

Untuk mengetahui keakuratan dari alat ini, dilakukan pengujian performa. Pengujian performa dilakukan dengan uji waktu kalibrasi. Untuk menentukan akurasi performa sistem digunakan error adalah konsentrasi sampel dikurang data konsentrasi cairan diketahui. Uji waktu kalibrasi dilakukan dengan cara melakukan pengujian dengan waktu yang berbeda saat kalibrasi. Jarak waktu pengujian dengan kalibrasi terakhir dan perawatan berkala (deproteinizing \& conditioning) termasuk parameter penting untuk menguji performa dari alat ini. Deproteinizing merupakan cara menghilangkan protein dan lemak pada saluran ISE menggunakan cairan pembersih atau dengan cairan aquades. Conditioning adalah cara untuk melakukan rekondisi dengan cara mengganti cairan pada ISE.

Setelah mendapatkan nilai kadar elektrolit, dilakukan pengujian waktu kalibrasi untuk mengetahui berapa kali dilakukan kalibrasi agar mendapatkan nilai yang maksimal. Pengujian ini dilakukan dengan cara melakukan pengukuran tegangan cairan standar diantara pengukuran tegangan cairan sampel. Sebagai contoh, dilakukan kalibrasi terlebih dahulu, lalu dilakukan pengukuran 2 cairan sampel yang berbeda, dan kemudian dilakukan pengukuran tegangan cairan standar kembali. Dengan harapan, 
tingkat akurasi akan semakin tinggi karena nilai tegangan cairan standar yang terus berubah.

Pada pengujian ini dilakukan 5 skema pengujian, dimana skema 1 dilakukan kalibrasi setiap selesai melakukan satu kali percobaan cairan sampel. Skema 2 dilakukan kalibrasi setelah selesai melakukan dua kali percobaan cairan sampel, sedangkan skema 3 dilakukan setelah melakukan tiga kali percobaan cairan sampel. Skema 4 dilakukan 2 kali kalibrasi, masing masing dilakukan setelah lima kali percobaan cairan sampel. Skema 5 dilakukan hanya satu kali kalibrasi diawal percobaan untuk 10 cairan sampel. Pada Tabel 3 ditampilkan hasil konversi nilai kadar elektrolit yang dilakukan dengan cara yang sama pada pengukuran sebelumnya dan juga berdasarkan Persamaan 1 serta mendapatkan tingkat akurasinya.

Tabel 3. Tabel akurasi kalibrasi

\begin{tabular}{|c|c|c|c|c|}
\hline \multirow{5}{*}{$\begin{array}{c}\text { Konsen } \\
\text { trasi } \\
\text { (mmol/ } \\
\text { L) }\end{array}$} & \multicolumn{4}{|c|}{ Hasil Konsentrasi (mmol/L) } \\
\hline & \multicolumn{3}{|c|}{ Akura } & Akur \\
\hline & Skem & si & Skem & asi \\
\hline & a 1 & Skem & a 2 & Ske \\
\hline & & a 1 & & ma 2 \\
\hline \multirow{2}{*}{110} & 110, & 99,76 & 110, & 99,5 \\
\hline & 26 & $\%$ & 45 & $9 \%$ \\
\hline 115 & 115, & 99,94 & 115 , & 99,5 \\
\hline
\end{tabular}

\begin{tabular}{|c|c|c|c|c|}
\hline & 07 & $\%$ & 48 & $8 \%$ \\
\hline \multirow{2}{*}{120} & 120 & 99,61 & 120, & 99,8 \\
\hline & 47 & $\%$ & 13 & $9 \%$ \\
\hline \multirow{2}{*}{125} & 125 & 99,21 & 126, & 98,4 \\
\hline & 99 & $\%$ & 96 & $3 \%$ \\
\hline \multirow{2}{*}{130} & 130, & 99,43 & 130, & 99,8 \\
\hline & 74 & $\%$ & 20 & $5 \%$ \\
\hline \multirow{2}{*}{135} & 135 & 99,94 & 141, & 94,9 \\
\hline & 07 & $\%$ & 88 & $0 \%$ \\
\hline \multirow{2}{*}{140} & 140 & & 140 & 99,4 \\
\hline & 23 & $\%$ & 75 & $7 \%$ \\
\hline \multirow{2}{*}{145} & 145 & & 145 & 99,9 \\
\hline & 23 & $\%$ & 01 & $9 \%$ \\
\hline \multirow{2}{*}{150} & 150 & 99,84 & 148 & 98,9 \\
\hline & 24 & $\%$ & 38 & $2 \%$ \\
\hline \multirow{2}{*}{154} & 154 & 99,69 & 154 & 99,9 \\
\hline & 48 & $\%$ & 05 & $7 \%$ \\
\hline \multicolumn{5}{|l|}{ Akurasi } \\
\hline Rata- & \multirow{2}{*}{\multicolumn{2}{|c|}{$99,71 \%$}} & \multirow{2}{*}{\multicolumn{2}{|c|}{$99,06 \%$}} \\
\hline Rata & & & & \\
\hline \multirow{5}{*}{$\begin{array}{c}\text { Konsen } \\
\text { trasi } \\
\text { (mmol/ } \\
\text { L) }\end{array}$} & \multicolumn{4}{|c|}{ Hasil Konsentrasi (mmol/L) } \\
\hline & \multicolumn{3}{|c|}{ Akuras } & Akur \\
\hline & Ske & $\mathrm{i}$ & Ske & asi \\
\hline & ma 3 & Skema & ma 4 & Ske \\
\hline & & 3 & & ma 4 \\
\hline \multirow{2}{*}{110} & 112, & 97,95 & 110 & 99,9 \\
\hline & 26 & $\%$ & 06 & $5 \%$ \\
\hline \multirow{2}{*}{115} & 115 & 99,90 & 115 & 99,9 \\
\hline & 11 & $\%$ & 11 & $1 \%$ \\
\hline \multirow{2}{*}{120} & 120 & 99,91 & 120 & 99,3 \\
\hline & 10 & $\%$ & 78 & $5 \%$ \\
\hline 125 & 125, & 99,66 & 141, & 86,9 \\
\hline
\end{tabular}




\begin{tabular}{|c|c|c|c|c|}
\hline & 42 & $\%$ & 27 & $8 \%$ \\
\hline \multirow{2}{*}{130} & 129 & 99,43 & 147 & 86,4 \\
\hline & 26 & $\%$ & 66 & $2 \%$ \\
\hline \multirow{2}{*}{135} & 135 & 99,64 & 120 , & 89,3 \\
\hline & 48 & $\%$ & 68 & $9 \%$ \\
\hline \multirow{2}{*}{140} & 140 & 99,53 & 140 & 99,6 \\
\hline & 66 & $\%$ & 43 & $9 \%$ \\
\hline \multirow{2}{*}{145} & 146 & 98,82 & 145 & 99,6 \\
\hline & 71 & $\%$ & 45 & $9 \%$ \\
\hline \multirow{2}{*}{150} & & 98,51 & & \\
\hline & 23 & $\%$ & 95 & $3 \%$ \\
\hline \multirow{2}{*}{154} & 154 & 99,86 & 152 & \\
\hline & 21 & $\%$ & 84 & $4 \%$ \\
\hline \multicolumn{5}{|l|}{ Akurasi } \\
\hline Rata- & \multirow{2}{*}{\multicolumn{2}{|c|}{$99,32 \%$}} & \multirow{2}{*}{\multicolumn{2}{|c|}{$95,93 \%$}} \\
\hline Rata & & & & \\
\hline \multirow{2}{*}{$\begin{array}{c}\text { Konsen } \\
\text { trasi } \\
\text { (mmol/ } \\
\text { L) }\end{array}$} & \multicolumn{4}{|c|}{ Hasil Konsentrasi (mmol/L) } \\
\hline & \multicolumn{2}{|c|}{ Skema 5} & \multicolumn{2}{|c|}{$\begin{array}{l}\text { Akurasi } \\
\text { Skema } 5\end{array}$} \\
\hline 110 & \multicolumn{2}{|c|}{110,127} & \multicolumn{2}{|c|}{$99,88 \%$} \\
\hline 115 & \multicolumn{2}{|c|}{115,729} & \multicolumn{2}{|c|}{$99,37 \%$} \\
\hline 120 & \multicolumn{2}{|c|}{121,126} & \multicolumn{2}{|c|}{$99,06 \%$} \\
\hline 125 & \multicolumn{2}{|c|}{140,93} & \multicolumn{2}{|c|}{$87,26 \%$} \\
\hline 130 & \multicolumn{2}{|c|}{147,045} & \multicolumn{2}{|c|}{$86,89 \%$} \\
\hline 135 & \multicolumn{2}{|c|}{142,336} & \multicolumn{2}{|c|}{$94,57 \%$} \\
\hline 140 & \multicolumn{2}{|c|}{141,163} & \multicolumn{2}{|c|}{$99,17 \%$} \\
\hline 145 & \multicolumn{2}{|c|}{145,753} & \multicolumn{2}{|c|}{$99,48 \%$} \\
\hline 150 & \multicolumn{2}{|c|}{148,431} & \multicolumn{2}{|c|}{$98,95 \%$} \\
\hline 154 & 185 & 897 & 79,2 & $9 \%$ \\
\hline $\begin{array}{c}\text { Akurasi } \\
\text { Rata- }\end{array}$ & & & & \\
\hline
\end{tabular}

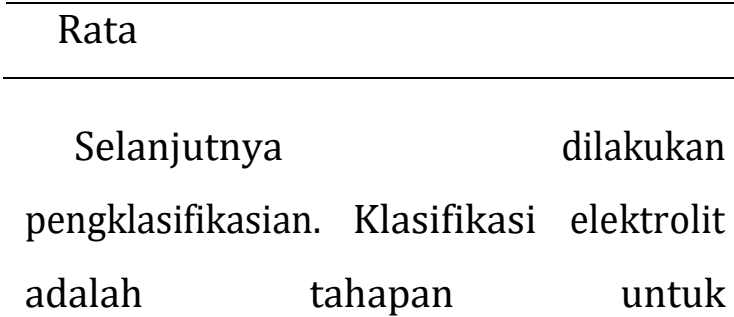
mengkasifikasikan kadar elektrolit ke dalam kondisi normal, hiponatremia, dan hipernatremia. Proses pengklasifikasian diawali dengan pengukuran tegangan cairan uji yang dihasilkan oleh ion selective electrode dibandingkan dengan tegangan cairan latih yang sudah ada. Pada Penelitian ini, digunakan metode k-NN sebagai metode pengklasifikasian dengan menggunakan nilai $\mathrm{K}=1,2,5,7$ dan perhitungan jarak menggunakan metode Euclidean, City-Block, Chebyshev, dan Minkowski.

Klasifikasi elektrolit dilakukan dengan mengguakan k-NN dengan menggunakan 1 fitur dan juga 2 fitur disetiap perhitungan jarak. Selain itu, dilakukan penghitungan threshold dengan manual dari hasil yang dikeluarkan dari ion selective electrode dan dikonversikan menggunakan Persamaan 1. Untuk data 1 fitur, digunakan data hasil konsentrasi terpilih dari ion selective electrode, sedangkan untuk data 2 fitur digunakan data yang berasal dari 2 konsentrasi cairan standar (110 
$\mathrm{mmol} / \mathrm{L}$ dan $140 \mathrm{mmol} / \mathrm{L}$ ).

Nilai akurasi tertinggi yang diperoleh dari 2 tipe data adalah $75 \%$ dengan menggunakan metode k-NN dengan pengukuran jarak Euclidean, City-Block, Chebychev, dan Minkowski dengan nilai $\mathrm{k}=1$ dan juga $\mathrm{k}=3$. Sedangkan perhitungan menggunakan threshold secara manual mendapatkan nilai akurasi pada setiap kelompok diperoleh nilai akurasi untuk hiponatremia $60 \%$, normal $50 \%$, dan hipernatremia 100\%.

\section{SIMPULAN}

Pengukuran kadar elektrolit Natrium membutuhkan Ion Selective Electrode dikarenakan terdapat membran yang dapat memisahkan kandungan natrium dalam cairan sampel. Dari tegangan yang dihasilkan ISE dapat dikonversikan menjadi kadar elektrolit, namun membutuhkan cairan standar, yaitu $110 \mathrm{mmol} / \mathrm{L}$ dan 140 mmol/L. Selain itu, nilai kadar elektrolit sangat dipengaruhi dari kondisi ISE yang digunakan. Parameter yang berpengaruh adalah pengukuran kalibrasi dan melakukan pembersihan menggunakan aquades secara teratur. Pengujian ini dilakukan dengan larutan sampel 110, 115, 120, 125, 130, 135, 140, 145, 150, dan $154 \mathrm{mmol} / \mathrm{L}$. Hasil dari pengujian kalibrasi adalah diperoleh tingkat akurasi yang tinggi, yaitu 99,7\% dengan melakukan kalibrasi setiap satu kali pembacaan cairan sampel. Sedangkan untuk pengelompokan, nilai akurasi tertinggi adalah $75 \%$ dengan menggunakan metode k-NN 1 fitur dengan pengukuran jarak Euclidean, City-Block, Chebychev, dan Minkowski dengan nilai $\mathrm{k}=1$ dan $\mathrm{k}=3$. Dimana nilai untuk hiponatremia adalah 60\%, untuk hipernatremia adalah $100 \%$, dan untuk normal adalah 83, 33\%.

\section{DAFTAR PUSTAKA}

A. R. L. Francisco, The Top Ten Algorithms in Data Mining, Chapman \& Hall/CRC Data Mining and Knowledge Discovery, vol. 53, no. 9. 2013.

D. T. Larose and C. D. Larose, Discovering Knowledge in Data: An Introduction to Data Mining: Second Edition, vol. 9780470908. 2014.

Fuadah, Y.N. \& Setiawan, Agung \& Mengko, Tlr. (2015). "Performing high accuracy of the system for cataract detection using statistical texture analysis and $\mathrm{K}$ Nearest Neighbor." 85-88. 10.1109/ISITIA.2015.7219958. 
J. M. A. Feri Fahrianto, "Perancangan Simulasi Pengkodean Hamming $(7,4)$ Untuk Menghitung Bit Error Rate (Ber) Pada Binary Symetric Channel," J. Tek. Inform., vol. 7, no. 2, pp. 24-34, 2014.

K. Chomboon, P. Chujai, P. Teerarassammee, K. Kerdprasop, and N. Kerdprasop, "An Empirical Study of Distance Metrics for k-Nearest Neighbor Algorithm," pp. 280-285, 2015, doi: 10.12792/iciae2015.051.

M. Nishom, "Perbandingan Akurasi Euclidean Distance, Minkowski Distance, dan Manhattan Distance pada Algoritma K-Means Clustering berbasis Chi-Square," J. Inform. J. Pengemb. IT, vol. 4 , no. 1 , pp. 2024, 2019.

M. Tinawi, "Hyponatremia and Hypernatremia: A Practical Guide to Disorders of Water Balance," Arch. Intern. Med. Res., vol. 03, no. 01, 2020.

M. A. jabbar, B. L. Deekshatulu, and P. Chandra, "Classification of Heart Disease Using K- Nearest Neighbor and Genetic Algorithm," Procedia Technol., vol. 10, pp. 8594, 2013.

P. K. Nagar, R. Maheshwari, and V.
Pandey, "An Approach of ion selective electrode for human body, cells and biomedical researches," Proc. - 2016 Int. Conf. Micro- Electronics Telecommun. Eng. ICMETE 2016, pp. 499-503, 2016.

R. Yaswir and I. Ferawati, "Tinjauan Pustaka Fisiologi dan Gangguan Keseimbangan Natrium, Kalium dan Klorida serta Pemeriksaan Laboratorium," vol. 1, no. 2, pp. 80-85, 2012.

S. Benyon and J. O. Roach, Crash Course Metabolism and Nutrition, 4th ed. United Kingdom: Elsevier, 2013.

S. Subairi, R. Rahmadwati, and E. Yudaningtyas, "Implementasi Metode k-Nearest Neighbor pada Pengenalan Pola Tekstur Citra Saliva untuk Deteksi Ovulasi," J. EECCIS, vol. 12, no. 1, pp. 9-14, 2018.

T. Afirianto, "Penerapan Fuzzy KNearest Neighbor Untuk Diagnosis Penderita Gagal Ginjal Kronis Berdasarkan Dataset Indians Chronic Kidney," no. August, 2017.

V. Vitasari, I. Uddin, S. N. Sofia, and G. Jantung, “Hiponatremia Sebagai 
Miftahul F, Raditiana P, R Yunendah, N. F, Azis, A. W, Perancangan dan Omplementasi Alat Pengukur Kadar Natrium Dalam Cairan

Prediktor Mortalitas Gagal

Jantung Studi Kasus Di Rsup Dr.

Kariadi Semarang," Diponegoro

Med. J. Uurnal Kedokt.

Diponegoro), vol. 7, no. 2, pp.

1585-1595, 2018.

W. Wahyono, I. N. P. Trisna, S. L.

Sariwening, M. Fajar, and D.

Wijayanto, "Comparison of

distance measurement on $\mathrm{k}$ -

nearest neighbour in textual

data classification," J. Teknol.

dan Sist. Komput., vol. 8, no. 1,

pp. 54-58, 2020, doi:

10.14710/jtsiskom.8.1.2020.54-

58. 